\title{
Simultaneous Assimilation and Denitrification of Nitrate by Bradyrhizobium japonicum
}

\author{
By F. VAIRINHOS, $\uparrow$ W. WALLACE* AND D. J. D. NICHOLAS \\ Department of Agricultural Biochemistry, Waite Agricultural Research Institute, University of \\ Adelaide, Glen Osmond, SA, 5064, Australia
}

(Received 8 August 1988; accepted 25 August 1988)

\begin{abstract}
Bradyrhizobium japonicum strain CB 1809 assimilated and denitrified ${ }^{15} \mathrm{NO}_{3}^{-}$simultaneously to ${ }^{15} \mathrm{NH}_{4}^{+}$and ${ }^{15} \mathrm{~N}_{2}$, respectively, when incubated under anaerobiosis. Washed cells from cultures grown in air in the presence of $5 \mathrm{mM}$-nitrate, assimilated $70 \%$ of the ${ }^{15} \mathrm{NO}_{3}^{-}$into cell-nitrogen but only after a lag of $10 \mathrm{~h}$ during which time $\mathrm{NO}_{2}^{-}$accumulated. In washed cells grown at $2 \%(\mathrm{v} / \mathrm{v})$ $\mathrm{O}_{2}$ with 5 mM-nitrate, ${ }^{15} \mathrm{NO}_{3}^{-}$was denitrified to ${ }^{15} \mathrm{~N}_{2}(95 \%)$ in $1-2 \mathrm{~h}$. The low $\mathrm{O}_{2}$ tension in the culture medium resulted in increased activity of nitrate and nitrite reductases in the cells. When $10 \mathrm{~mm}$-glutamate was included with $5 \mathrm{mM}$-nitrate at $2 \%(\mathrm{v} / \mathrm{v}) \mathrm{O}_{2}$, washed cells from these cultures had less nitrate and nitrite reductase activities and when ${ }^{15} \mathrm{NO}_{3}^{-}$was supplied to these cells there was a transient accumulation of $\mathrm{NO}_{2}^{-}(1 \mathrm{~h})$ prior to maximum denitrification. Washed cells prepared from cultures grown at $2 \%(\mathrm{v} / \mathrm{v}) \mathrm{O}_{2}$ with glutamate alone utilized ${ }^{15} \mathrm{NO}_{3}^{-}$, only after a lag period of $20-40 \mathrm{~h}$, assimilation by $(60 \%)$ and denitrification $(40 \%)$.
\end{abstract}

\section{INTRODUCTION}

The metabolism of nitrate may occur by two pathways: assimilation via ammonium into cellnitrogen or denitrification of $\mathrm{N}_{2} \mathrm{O}$ and $\mathrm{N}_{2}$. In both cases nitrite is an intermediate but the interrelationship between the pathways has not been studied. Many strains of rhizobia utilize nitrate for growth (Bergersen, 1977) and the slow-growing strains (bradyrhizobia) can also denitrify nitrate (Zablotowicz et al., 1978; Daniel et al., 1982; O’Hara \& Daniel, 1985).

In Bradyrhizobium japonicum, denitrification is derepressed by anaerobic conditions (O'Hara et al., 1983), as in other denitrifiers (Knowles, 1982). In some micro-organisms nitrate is required for the production of dissimilatory nitrate reductase (NR) (Kapralék et al., 1982), but not in B. japonicum (O'Hara et al., 1983).

The aim of this study was to determine whether assimilation and denitrification of $\left[{ }^{15} \mathrm{~N}\right]$ nitrate in washed cells of $B$. japonicum strain CB 1809 occurred concurrently, and to consider the influence of $\mathrm{O}_{2}$ tension and nitrogen supply in the culture medium on the operation of these pathways. Strain CB 1809 is a strain used commercially in Australia for the inoculation of soybean.

\section{METHODS}

Bacteria and growth conditions. Bradyrhizobium japonicum strain CB 1809 was supplied by Dr A. H. Gibson from the CSIRO Division of Plant Industry, Canberra, ACT, Australia. Cells were cultured at $28^{\circ} \mathrm{C}$ in defined liquid medium (1 1 in 21 Erlenmeyer flasks) containing mineral salts and 15 mM-glucose (Dalton, 1980). The nitrogen source was either $\mathrm{KNO}_{3}$ or glutamate at the concentrations indicated in the text. Aerobically grown cells were shaken on a rotary reciprocator while cells grown under an atmosphere of $2 \% \mathrm{O}_{2} / 98 \% \mathrm{~N}_{2}(\mathrm{v} / \mathrm{v})$ were flushed continuously through glass sintered discs with this gas mixture. The final concentration of each gas in the mixture

† Present address: Département de Sciences Biologiques, Université de Montréal, Canada.

Abbreviations: NR, nitrate reductase; NiR, nitrite reductase. 
was monitored by measuring individual flow rates through two rotameters. Cells were harvested at the late exponential phase of growth in a Sorvall RC-2B centrifuge, fitted with a GSA rotor (Sorvall), at $100 \mathrm{~g}$ for $10 \mathrm{~min}$ $\left(4^{\circ} \mathrm{C}\right)$ followed by centrifugation at $10000 \mathrm{~g}$ for $10 \mathrm{~min}\left(4^{\circ} \mathrm{C}\right)$. They were washed with $100 \mathrm{~mm}$-potassium phosphate buffer $(\mathrm{pH} 7.5)$ and resuspended in the same buffer. Anaerobic conditions were maintained by sparging the buffer with Ar and centrifuging under Ar (99.9\% pure; Commonwealth Industrial Gases, Cowandilla, S. Australia).

${ }^{15} \mathrm{~N}$ studies. Suspensions of cultured cells were incubated, for the time period indicated, in $3.5 \mathrm{ml}$ sealed tubes fitted with suba-seals at $25^{\circ} \mathrm{C}$ in an assay mixture $(2 \mathrm{ml})$ which contained $100 \mathrm{mmol}$ potassium phosphate buffer (pH 7.5), $4 \mu \mathrm{mol} \mathrm{K}{ }^{15} \mathrm{NO}_{3}$ (97 atom \% excess), $40 \mu \mathrm{mol}$ sodium succinate and $2 \mathrm{mg}$ cell protein. The assay mixture (minus $\mathrm{KNO}_{3}$ ) was degassed with a water pump for 2-3 min and then flushed with Ar for $10 \mathrm{~min}$. The assay was started by the addition of the $\mathrm{K}^{15} \mathrm{NO}_{3}$ solution which had also been degassed and flushed with Ar. Samples (20$50 \mu \mathrm{l})$ were removed with a microsyringe at regular intervals for the determination of nitrate and nitrite. Gas samples $\left(100 \mu\right.$ l) were analysed for ${ }^{15} \mathrm{~N}_{2} \mathrm{O}$ and ${ }^{15} \mathrm{~N}_{2}$ in a GC/mass spectrometer (model 592B; Hewlett-Packard) fitted with a glass column ( $183 \mathrm{~cm}$ length, $6 \mathrm{~mm}$ outer diameter, $2 \mathrm{~mm}$ inner diameter) packed with Porapak $Q$ (80-100 mesh). Helium flow through the column was $5 \mathrm{ml} \mathrm{min}^{-1}$ at $25^{\circ} \mathrm{C}$ and the electron multiplier voltage varied between 1400 and $2000 \mathrm{~V}$. The data was assembled by means of a selective Ion Monitor programme (HewlettPackard) which allowed the simultaneous monitoring of six specified atomic-mass-unit values $(28,29,30,40,44$, 46). Ar was used as an internal standard to allow comparison between injections when sample size may have varied. ${ }^{15} \mathrm{~N}_{2} \mathrm{O}$ was calibrated against a standard curve of $\mathrm{N}_{2} \mathrm{O}$ with the solubility of $\mathrm{N}_{2} \mathrm{O}$ in liquid taken into account (Byrne \& Nicholas, 1986). ${ }^{15} \mathrm{~N}_{2}$ was calibrated against a standard curve of a gas mixture of ${ }^{15} \mathrm{~N}_{2} /{ }^{14} \mathrm{~N}_{2}$, prepared by adding hypobromite solution to $\left({ }^{15} \mathrm{NH}_{4}\right)_{2} \mathrm{SO}_{4}\left(37.5\right.$ atom \% excess). ${ }^{15} \mathrm{NH}_{4}^{+}$was determined by first liberating ${ }^{15} \mathrm{NH}_{3}$ from the assay mixture (Conway, 1962) and then measuring ${ }^{15} \mathrm{~N}$ enrichment of samples in an Isomass 602E mass spectrometer (Middlewich, Cheshire, UK), according to the procedure of Brownell \& Nicholas (1967). ${ }^{15} \mathrm{~N}$ incorporated into cell-nitrogen was also determined by mass spectrometry after digestion and distillation of samples (Markham, 1942).

Nitrate reductase $(N R)$ and nitrite reductase (NiR) activities. These were determined for washed cells using the same assay mixture as for ${ }^{15} \mathrm{~N}$ studies, except that unlabelled $\mathrm{KNO}_{3}\left(2 \mu \mathrm{mol} \mathrm{ml}^{-1} ; \mathrm{NR}\right)$ or $\mathrm{NaNO}_{2}\left(2 \mu \mathrm{mol} \mathrm{ml}^{-1}\right.$; $\mathrm{NiR})$ were used. Samples $(20-50 \mathrm{ml})$ were removed after appropriate intervals $(5-60 \mathrm{~min})$ for nitrite determination. Sodium diethyl dithiocarbamate $(1 \mathrm{mM})$ was included in the assay mixture to inhibit NiR when determining NR activities.

Nitrate and nitrite determination. Nitrate was determined by nitration of salicylic acid (Cataldo et al., 1975) and nitrite by the method of Nicholas \& Nason (1957).

Protein determination. Protein in washed cells was determined by the microbiuret method (Itzhaki \& Gill, 1964) using bovine serum albumin (BSA) as a standard protein.

\section{RESULTS}

Washed cells of $B$. japonicum strain CB 1809 grown at $20 \%$ (v/v) $\mathrm{O}_{2}$ with 5 mm-nitrate were supplied with ${ }^{15} \mathrm{NO}_{3}$ under anaerobic conditions. About $70 \%$ of the ${ }^{15} \mathrm{NO}_{3}^{-}$was reduced to ${ }^{15} \mathrm{NH}_{4}^{+}$over a $20 \mathrm{~h}$ period while the remainder was denitrified to ${ }^{15} \mathrm{~N}_{2}$ (Fig. 1 a). Under the same conditions, cells which had been grown under $2 \%(\mathrm{v} / \mathrm{v}) \mathrm{O}_{2}$ denitrified $95 \%$ of the ${ }^{15} \mathrm{NO}_{3}^{-}$(Fig. $1 \mathrm{~b}$ ); the remainder was reduced to ${ }^{15} \mathrm{NH}_{4}^{+}$. In this case the reduction of ${ }^{15} \mathrm{NO}_{3}^{-}$to ${ }^{15} \mathrm{~N}_{2}$ and ${ }^{15} \mathrm{NH}_{4}^{+}$was complete within $2 \mathrm{~h}$. Washed cells which had been cultured under $2 \%(\mathrm{v} / \mathrm{v}) \mathrm{O}_{2}$ exhibited a more rapid utilization of ${ }^{15} \mathrm{NO}_{3}^{-}$under anaerobic conditions than those grown in air (Fig. $1 a, b)$. In contrast to a transient accumulation $\left(<1 \mathrm{~h}\right.$ ) of a low level of $\mathrm{NO}_{2}^{-}$by cells grown at $2 \%(\mathrm{v} / \mathrm{v}) \mathrm{O}_{2}$ (Fig. $\left.1 \mathrm{~b}\right)$, the aerobically grown cells exhibited a prolonged accumulation $(10 \mathrm{~h})$ of a higher concentration of $\mathrm{NO}_{2}^{-}$under anaerobiosis (Fig. $1 a$ ) and then it was utilized rapidly.

These observations on ${ }^{15} \mathrm{NO}_{3}^{-}$utilization are correlated with the activities of NR and NiR (Table 1). Cells grown at $2 \%(\mathrm{v} / \mathrm{v}) \mathrm{O}_{2}$ had higher $\mathrm{NR}$ and $\mathrm{NiR}$ activities than those from cultures grown in air. A much larger increase in NiR activity was observed.

Cells which had been cultured at $2 \%(\mathrm{v} / \mathrm{v}) \mathrm{O}_{2}$ with glutamate and nitrate showed a more pronounced accumulation of $\mathrm{NO}_{2}^{-}$, when incubated anaerobically with ${ }^{15} \mathrm{NO}_{3}^{-}$, than those grown with nitrate alone (Fig. $1 b, c$ ). The former had a lower NiR activity (Table 1). In the nitrate plus glutamate grown cells, denitrification to ${ }^{15} \mathrm{~N}_{2}$ in washed cells increased markedly after a lag period of $1 \mathrm{~h}$ reaching a final value of $80 \%$ of the ${ }^{15} \mathrm{NO}_{3}^{-}$supplied (Fig. $1 c$ ) compared to $95 \%$ for nitrate grown cells (Fig. $1 b$ ). 

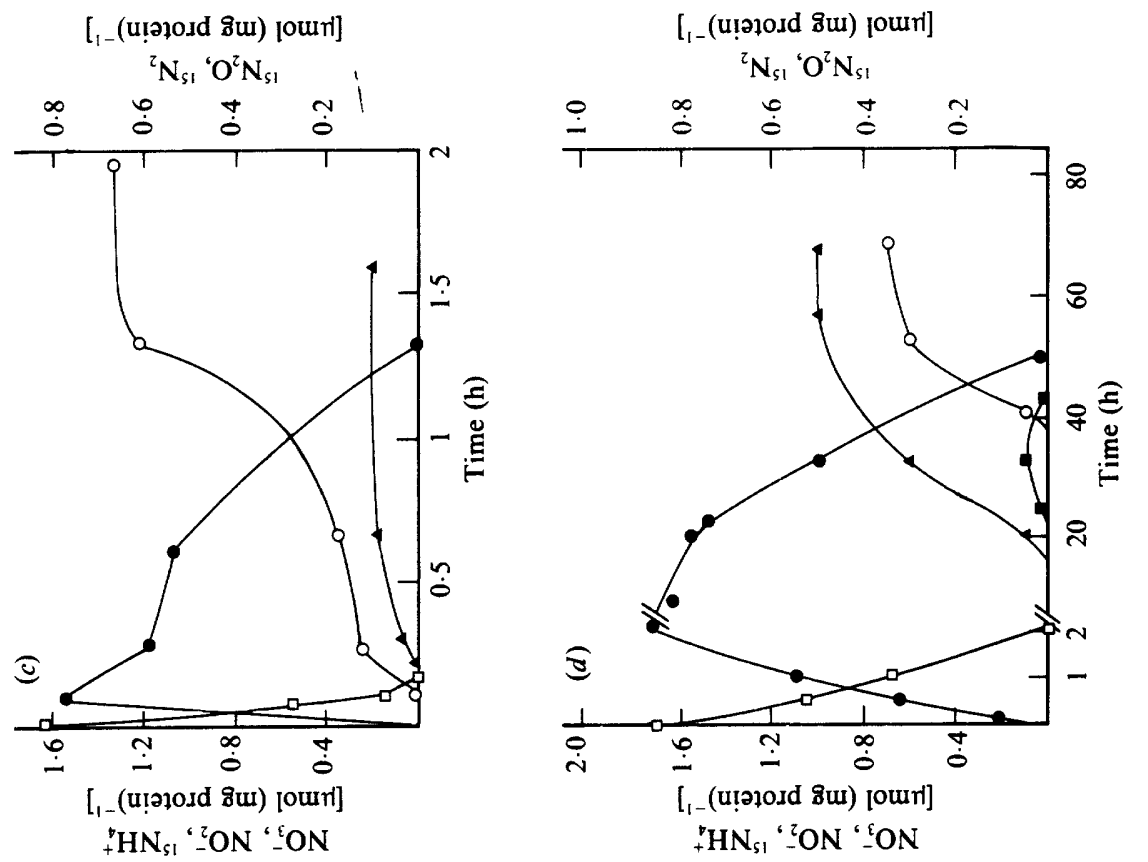

ํํำ

$\Xi \Xi$

몽

कิ

웛

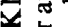

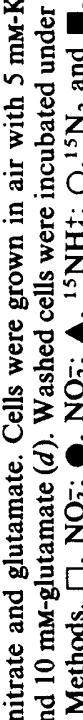

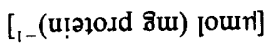

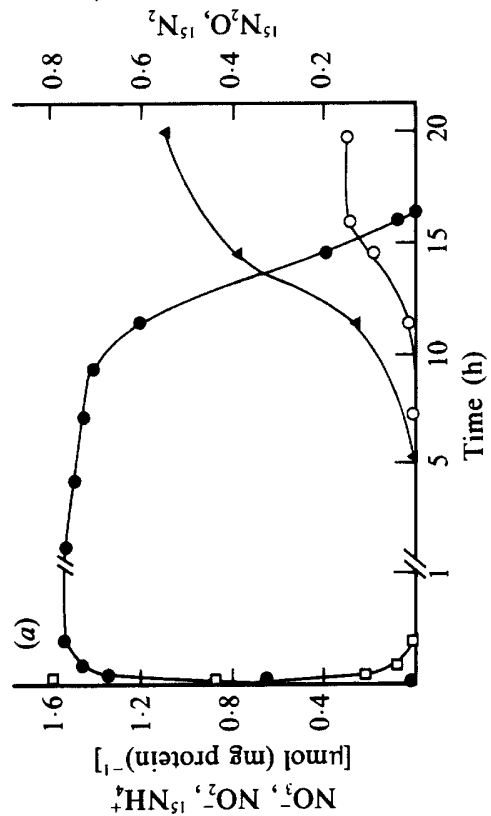

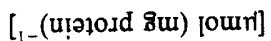

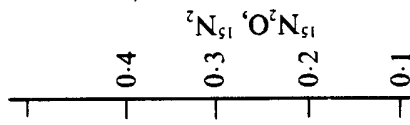

帘

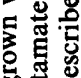

醇

急

.

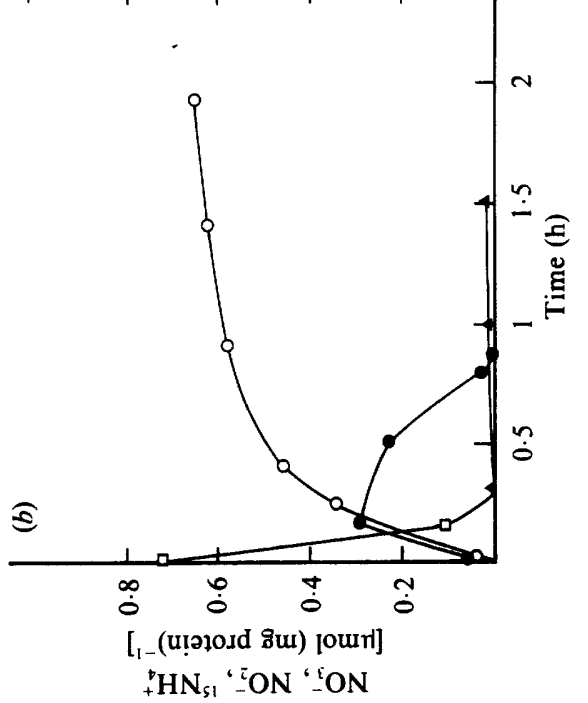

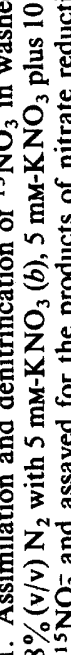


Table 1. Influence of $\mathrm{O}_{2}$ tension and nitrogen source on NR and NiR activities

Cells were grown both aerobically and under $2 \%(\mathrm{v} / \mathrm{v}) \mathrm{O}_{2} / 98 \%(\mathrm{v} / \mathrm{v}) \mathrm{N}_{2}$ in defined medium containing $5 \mathrm{~mm}-\mathrm{KNO}_{3}$ and $10 \mathrm{~mm}$-glutamate as indicated. Activities are expressed in $\mu \mathrm{mol}$ nitrite produced (NR) or utilized (NiR) $\mathrm{h}^{-1}$ (mg protein) ${ }^{-1}$.

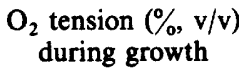

20

2

2

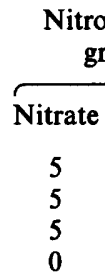

Nitrogen source for growth (mM)

Glutama
0
0
10
10

$\begin{array}{cc}\begin{array}{c}\text { NR } \\ \text { activity }\end{array} & \begin{array}{c}\text { NiR } \\ \text { activity }\end{array} \\ 6.90 & 0 \cdot 24 \\ 14.40 & 4 \cdot 20 \\ 14.70 & 1 \cdot 40 \\ 2.50 & 0 \cdot 12\end{array}$

Cells grown with glutamate at $2 \%(\mathrm{v} / \mathrm{v}) \mathrm{O}_{2}$ utilized ${ }^{15} \mathrm{NO}_{3}^{-}$, under anaerobic conditions, at a considerably slower rate than those grown on nitrate at the same $\mathrm{O}_{2}$ tension (Fig. 1d). There was also a pronounced and prolonged accumulation of $\mathrm{NO}_{2}^{-} ;{ }^{15} \mathrm{NH}_{4}^{+}$and ${ }^{15} \mathrm{~N}_{2}$, were only detected in washed cells after a $20-40 \mathrm{~h}$ incubation with ${ }^{15} \mathrm{NO}_{3}^{-}$. Only $40 \%$ of the ${ }^{15} \mathrm{NO}_{3}^{-}$supplied was denitrified and the remainder reduced to ${ }^{15} \mathrm{NH}_{4}^{+}$. The glutamate grown cells had relatively low activities of NR and NiR compared to those cultured with nitrate (Table 1).

\section{DISCUSSION}

Anaerobic growth supported by denitrification has been demonstrated in several strains of bradyrhizobia (Van Berkum \& Keyser, 1985), but hitherto it has not been established in rhizobia or other bacteria whether denitrification and assimilation of nitrate into cell-nitrogen can occur concurrently. In this study on $B$. japonicum the simultaneous reduction of ${ }^{15} \mathrm{NO}_{3}^{-}$to ${ }^{15} \mathrm{NH}_{4}^{+}$and denitrification of ${ }^{15} \mathrm{NO}_{3}^{-}$to ${ }^{15} \mathrm{~N}_{2}$ is demonstrated.

The ratio of denitrification to assimilation was influenced by the conditions under which the $B$. japonicum cells were grown. Even though the anaerobic conditions used to follow the utilization of ${ }^{15} \mathrm{NO}_{3}^{-}$would have favoured the production of the denitrifying enzymes (O'Hara $e t$ al., 1983), cells grown in air still assimilated $70 \%$ of the ${ }^{15} \mathrm{NO}_{3}^{-}$supplied to the washed cells. When cells were cultured under $2 \%(\mathrm{v} / \mathrm{v}) \mathrm{O}_{2}$ about $95 \%$ of the ${ }^{15} \mathrm{NO}_{3}^{-}$was denitrified by washed cells. An increase in the capacity of cells to denitrify nitrate at low $\mathrm{O}_{2}$ tensions is in accord with the results of O'Hara et al. (1983) who demonstrated an inhibition of denitrification by $\mathrm{O}_{2}$ in B. japonicum.

The greater capacity of the cells to denitrify when grown under $2 \%(v / v) \mathrm{O}_{2}$ correlates well with the increased activities of NR and in particular NiR. In many denitrifying bacteria, $\mathrm{NiR}$ is more sensitive to $\mathrm{O}_{2}$ inhibition than $\mathrm{NR}$, especially when the NiR has a cytochrome oxidase activity associated with a cytochrome $d$ component (Lam \& Nicholas, 1969; Krul \& Veeningen, 1977; Meiberg et al., 1980). There is good evidence that the nitrogen oxide reductases in denitrifying bacteria are derepressed at low $\mathrm{O}_{2}$ tensions (Knowles, 1982) and that there are separate assimilatory and dissimilatory NR and NiR enzymes (Payne 1981).

It is not clear whether decreased $\mathrm{O}_{2}$ tension alone fully derepresses denitrification or whether nitrate is also involved. O'Hara et al. (1983) claimed that the synthesis of the denitrifying enzymes in bradyrhizobia was independent of nitrate. However, based on results of the present study it is clear that the high rate of denitrification in cells of $B$. japonicum grown at $2 \%(\mathrm{v} / \mathrm{v}) \mathrm{O}_{2}$ is dependent on the presence of nitrate. Cells grown with glutamate alone utilized nitrate and especially nitrite at much slower rates and nitrate was assimilated to ammonium to a greater extent than its denitrification to $\mathrm{N}_{2}$ gas.

The award of a postgraduate scholarship from the Wheat Industry Research Council of Australia (FV) is gratefully acknowledged and the authors thank David Hein, Mike Byrne and Richard Batt for their technical assistance. 


\section{REFERENCES}

Bergersen, F. J. (1977). Physiological chemistry of dinitrogen fixation by legumes. In $A$ Treatise on Dinitrogen Fixation, vol. 3, pp. 519-555. Edited by R. W. F. Hardy \& W. S. Silver. New York: John Wiley and Sons.

Brownell, P. F. \& Nicholas, D. J. D. (1967). Some effects of sodium on nitrate assimilation and $\mathrm{N}_{2}$ fixation in Anabaena cylindrica. Plant Physiology 42, 915-921.

BYRNe, M. D. \& Nicholas, D. J. D. (1986). Multiplephase equilibration head space analysis for the determination of $\mathrm{N}_{2} \mathrm{O}$ and $\mathrm{N}_{2}$ during bacterial denitrification. Analytical Biochemistry 154, 470475.

Cataldo, D. A., Harron, M., Schrader, L. E. \& YouNGS, V. L. (1975). Rapid colorimetric determination of nitrate in plant tissues by nitration of salicylic acid. Communication in Soil Science and Plant Analysis 6, 71-80.

CONWAY, E. J. (1962). Microdiffusion Analysis and Volumetric Error. London: Crosby, Lockwood and Son.

Dalton, H. (1980). The cultivation of diazotrophic microorganisms. In Methods for Evaluating Biological Nitrogen Fixation, pp. 13-64. Chichester: John Wiley and Sons.

Daniel, R. M., Limmer, A. W., Steele, K. W. \& SMITH, J. M. (1982). Anaerobic growth, nitrate reduction and denitrification in 46 Rhizobium strains. Journal of General Microbiology 128, 18111815.

ITZHAKI, R. F. \& GILL, D. M. (1964). A microbiuret method for estimating proteins. Analytical Biochemistry 9, 401-410.

KaPralék, F., Jechova, E. \& Otavova, M. (1982). Two sites of oxygen control in induced synthesis of respiratory nitrate reductase in Escherichia coli. Journal of Bacteriology 149, 1142-1145.

KNOWLes, R. (1982). Denitrification. Microbiological Reviews 46, 43-70.
KRUL, J. M. \& VeEningen, R. (1977), The synthesis of the dissimilatory nitrate reductase under aerobic conditions in a number of denitrifying bacteria, isolated from activated sludge and drinking water. Water Research 11, 39-43.

LaM, Y. \& NicholaS, D. J. D. (1969). A nitrate reductase from Micrococcus denitrificans. Biochimica et biophysica acta 178, 225-234.

MARKHAM, R. (1942). A steam distillation apparatus suitable for micro-kjeldahl analysis. Journal of Biochemistry 36, 790-791.

Meiberg, J. B. M., Bruinenberg, P. M. \& Harder, W. (1980). Effect of dissolved oxygen tension on the metabolism of methylated amines in Hyphomicrobium $\mathrm{X}$ in the absence and presence of nitrate: evidence for 'aerobic' denitrification. Journal of General Microbiology 120, 453-463.

Nicholas, D. J. D. \& Nason, A. (1957). Determination of nitrate and nitrite. Methods in Enzymology 3, 981-984.

O'HARA, G. W. \& DANIEL, R. M. (1985). Rhizobial denitrification: a review. Soil Biology and Biochemistry 17, 1-9.

O'Hara, G. W., Daniel, R. M. \& Steele, K. W. (1983). Effect of oxygen on the synthesis, activity and breakdown of the rhizobium denitrification system. Journal of General Microbiology 129, 24052412.

PaYne, W. J. (1981). Denitrification. New York: John Wiley \& Sons.

VAN Berkum, P. \& KeYSER, H. H. (1985). Anaerobic growth and denitrification among different serogroups of soybean rhizobia. Applied and Environmental Microbiology 49, 772-777.

Zablotowicz, R. M., EsKew, D. L. \& Focht, D. D. (1978). Denitrification in Rhizobium. Canadian Journal of Microbiology 24, 757-760. 